\title{
Review
}

\section{ETHYLENE AND LETTUCE SEED GERMINATION}

\author{
Warley Marcos Nascimento \\ Embrapa Hortaliças, C. P. 218 - 70359-970 - Brasília,DF - Brasil.E-mail <wmn@cnph.embrapa.br>
}

\begin{abstract}
Ethylene can stimulate seed germination and overcome dormancy in many species. For instance, the inhibitory effect of high temperature on lettuce seed germination can be overcome by exogenous ethylene. Involvement of ethylene in seed germination is a widely accepted fact, but the mechanistic details are poorly understood. A critical factor in ethylene studies is the response of seed germination properties to various ethylene inhibitors. Lettuce seed has been used as a model to study the role of ethylene in seed germination at high temperature. The role of ethylene in germination is not known but either ethylene evolution or addition of 1-aminocyclopropane-1-carboxilic acid (ACC) have been associated with increased activity of endo- $\beta$ mannanase, a cell-wall enzyme that weakens the endosperm and allows lettuce seed to germinate at high temperature. This review describes some results on seed germination studies in response to ethylene and its possible role in promoting germination at high temperature.

Key words: Lactuca sativa, thermoinhibition, dormancy, enzyme activity
\end{abstract}

\section{ETILENO E A GERMINAÇÃO DE SEMENTES DE ALFACE}

\begin{abstract}
RESUMO: Etileno pode estimular a germinação e superar a dormência de sementes em várias espécies. O efeito inibitório de altas temperaturas na germinação de sementes de alface, por exemplo, pode ser superado pela aplicação de etileno. Embora o envolvimento deste hormônio na germinação seja aceito, os seus mecanismos não são bem entendidos. Um fator crítico nos estudos com etileno é a germinação em resposta aos diferentes inibidores de etileno. A semente de alface tem sido utilizada como modelo nos estudos com etileno, principalmente sob condições de altas temperaturas. O papel exato deste hormônio não é conhecido, mas tanto a produção do mesmo como a adição de seu precursor (1-aminociclopropano-1- ácido carboxílico - ACC) têm sido associados ao aumento da atividade da endo- $\beta$-mananase, uma enzima da parede celular que enfraquece o endosperma e permite as sementes de alface germinarem sob condições de altas temperaturas. Este artigo descreve alguns resultados de estudos com germinação de sementes de alface em resposta ao etileno e seu possível papel na germinação.

Palavras-chave: Lactuca sativa, termo-inibição, dormência, atividade enzimática
\end{abstract}

\section{INTRODUCTION}

Ethylene can stimulate germination and overcome dormancy in many seeds (Abeles et al., 1992; Esashi, 1991). For instance, the inhibitory effect of high temperature on lettuce seed germination can be overcome by exogenous ethylene (Abeles \& Lonski, 1969; Burdett, 1972a; Negm et al., 1972; Keys et al., 1975; Rao et al., 1975; Dunlap \& Morgan, 1977; Fu \& Yang, 1983; Abeles, 1986; Saini et al., 1986; Khan \& Prusinski, 1989; Saini et al., 1989; Huang \& Khan, 1992, Nascimento, 1998; Nascimento et al., 1999a; 1999b). Involvement of ethylene in seed germination is a widely accepted fact, but the mechanistic details are poorly understood.

\section{Ethylene, high temperature and seed germination}

High temperatures $\left(35^{\circ} \mathrm{C}\right)$ may inhibit seed germination of most lettuce cultivars (Cantliffe et al., 2000). High temperatures $\left(35\right.$ to $\left.40^{\circ} \mathrm{C}\right)$ also inhibit ethylene production in a number of plant tissues (Yu et al., 1980). For instance, the negative effect of high temperature on chickpea seed germination reported by Gallardo et al. (1991) was related to low ethylene production. These authors also reported that treating seeds with ethylene alleviated the inhibitory effects of supraoptimal temperatures, and observed that high temperatures decreased the levels of free ACC in chickpea seeds. In lettuce, ethylene evolution as well as sensitivity to ethylene decreased at high temperature imbibition (Burdett, 1972a; Dunlap \& Morgan, 1977; Abeles, 1986; Khan \& Huang, 1988; Nascimento, 1998). High temperature appears to inhibit the conversion of 1-aminocyclopropane-1-carboxylic acid (ACC) to ethylene in lettuce seed (Khan \& Prusinski, 1989).

Stress-induced, ethylene-like symptoms have revealed a complex interplay of effects on biosynthesis of and sensitivity to ethylene (Morgan \& Drew, 1997). Therefore, the requirement for endogenous ethylene production in lettuce seeds may be minimal for germination at temperatures between 20 and $25^{\circ} \mathrm{C}$. However, lettuce 
seeds imbibed at stress conditions (i.e., directly at $35^{\circ} \mathrm{C}$ ), do not germinate unless ethylene is added, and ACC synthesis is not detectable at this temperature (Huang \& Khan, 1992). Likewise, the conversion of ACC to ethylene decreased as the imbibition temperature of lettuce seed increased from 25 to $35^{\circ} \mathrm{C}$. The conversion of ACC to ethylene was inhibited at high temperatures and the conversion of ACC to ethylene was more sensitive to inactivation by high temperature than by ACC synthesis. Conversion of ACC to ethylene might in fact be the primary site of high temperature inactivation of this process which, in turn, does not allow germination to proceed at high temperatures (Prusinski \& Khan, 1990).

High temperatures may inhibit ethylene production, but may also raise the threshold concentration of ethylene required for lettuce seed germination. Several authors reported that ethylene synthesis or sensitivity to ethylene action in lettuce decreased during seed imbibition at high temperature (Burdett, 1972a; Dunlap \& Morgan, 1977; Abeles, 1986; Khan \& Huang, 1988). Abeles (1986) reported that exogenous ethylene overcame thermoinhibition at $30^{\circ} \mathrm{C}$, but not at $33^{\circ} \mathrm{C}$ in the dark. Similar results were also reported by Dunlap \& Morgan (1977), who reported that exogenous ethylene promoted germination at $32^{\circ} \mathrm{C}$ but not at $36^{\circ} \mathrm{C}$. However, early work by Abeles \& Lonski (1969) reported that ethylene did not overcome thermodormancy in lettuce seeds when dormancy resulted from action of high temperature. They could, however, stimulate lettuce seed to germinate at high temperature before they become thermodormant, thus bypassing thermodormancy.

Ethylene action appears to be limited to the early steps of germination, since treatment of dormant seeds with ethylene had no effect on germination (Abeles \& Lonski, 1969). Burdett (1972a) reported an increase in ethylene production in lettuce seeds as temperature increased from $20^{\circ}$ to $30^{\circ} \mathrm{C}$; thus ethylene production was not though to be a limiting factor for germination at temperatures up to $30^{\circ} \mathrm{C}$. Ethylene led to some softening of the endosperm tissue; however this effect was not correlated with the effect of ethylene as a germination promoter (Abeles, 1986).

Abeles (1986) suggested that the action of ethylene in lettuce seed germination was the promotion of embryonic hypocotyl cell expansion. Dutta \& Bradford (1994) also suggested that ethylene acts primarily on the embryo rather than on enveloping tissues and that ACC (via conversion to ethylene) extended the high temperature limit for lettuce seed germination by acting in the embryo as to maintain a water potential low enough to promote the initiation of growth at higher temperatures.

\section{Possible mechanisms of ethylene action during seed germination}

Ketring (1977) suggested some possibilities for the mechanism of ethylene action during seed germina- tion: a) by interaction with endogenous hormones (e.g., abscisic acid - ABA); b) by interaction with growth promoters required to maximize a given physiology response; c) by interaction in physiological response not specific for a single growth promoter; and d) by affecting enzyme synthesis and secretion.

ABA reduces ethylene production by dormant, imbibed and after-ripened non-dormant peanut seeds (Ketring \& Morgan, 1970). ABA also inhibits both ethylene production and germination of chickpea seeds (Gallardo et al., 1991). Exogenous ethylene overcome the inhibitory effects of ABA on germination of dormant peanut seeds (Ketring \& Morgan, 1970). The release of dormancy in lettuce seeds by ethylene, however, was not a result of decreasing on ABA-like compounds (Rao et al., 1975), since that ethrel-induced germination during seed imbibition was impaired in the presence of ABA. In recent studies using ethylene response mutants of Arabidopsis sp., endogenous ethylene promoted seed germination by decreasing sensitivity to endogenous ABA (Beaudoin et al., 2002). Other mutants, defective in their response to ethylene, also showed altered ABA synthesis. Ethylene appears to be a negative regulator of ABA during germination (Ghassemian et al., 2002).

Ethylene may interact with light or gibberellin to promote germination at high temperature. For example, ethylene promoted germination of lettuce in the dark only in the presence of gibberellin (Dunlap \& Morgan, 1977). Gibberellin slightly stimulates ethylene production in peanut seeds at $28^{\circ} \mathrm{C}$ (Ketring \& Morgan, 1970). The action of gibberellin in lettuce seed germination might be through promotion of ethylene synthesis, and ethylene might then stimulate germination by other mechanism (Stewart \& Freebairn, 1969). Burdett \& Vidaver (1971) found that both ethylene and gibberellin were necessary to stimulate germination of lettuce at high temperature.

Heat treatment of Spergula arvensis at $30^{\circ} \mathrm{C}$ prevented ethylene-promoted germination in the dark, but the inhibition was reversed by red light (Olatoye \& Hall, 1972). The inability of lettuce seeds to germinate at supraoptimal temperatures was not related to a rapid loss of far red-absorbing phytochrome, nor to inadequate ethylene synthesis (Burdett, 1972b). Moreover, Abeles \& Lonskin (1969) reported that the ability of ethylene initiating small increases in germination of lettuce did not result from phytochrome control of ethylene production, apparently. More likely red light does not promote germination of lettuce seeds by influencing ethylene production. However, ethylene produced by lettuce seeds in the light was slightly higher than in the dark at 20, 27.5 and $35^{\circ} \mathrm{C}$, and seeds imbibed at $35^{\circ} \mathrm{C}$ in the dark did not germinate and did not produce ethylene. Under the light, germination was $94 \%$ and the seeds produced abundant ethylene. The amount of ethylene produced after 10 hours 
imbibition (before radicle protrusion) was positively correlated with germination $(\mathrm{r}=0.90)$ (Nascimento \& Cantliffe, 1999; 2000).

Ethylene evolution from light-treated lettuce seeds began to increase two hours prior to radicle protrusion, whereas the dark-incubated (nongerminating) seeds produced a low, constant amount of ethylene (Saini et al., 1989). Therefore, a higher amount of endogenous ethylene was essential for the light-induced relief of thermoinhibition of germination of lettuce seed. Under osmotic conditions, the promotive effect of ethylene in the germination of lettuce seed was controlled by phytochrome (Negm \& Smith, 1978). Ethylene might contribute to the enhancement of the seed priming effect by abundant supply of amino acids in cocklebur seeds (Yoshiyama et al., 1996).

Ethylene synthesis and action are essential for the alleviation of thermoinhibition of lettuce seeds by combinations of $\mathrm{GA}_{3}$, kinetin, and $\mathrm{CO}_{2}$ (Saini et al., 1986). Negm et al. (1972) reported that $\mathrm{CO}_{2}$ was required for ethylene action to overcome thermodormancy in lettuce seeds, but ethylene did not enhance respiration. Cytokinins stimulate ethylene production by some seeds (Khan \& Huang, 1988). The relief of salt stress and thermoinhibition of lettuce seed germination by kinetin was accompanied by enhancement of ethylene production at pregermination. When cytokinins and ethylene are used together, the stress of high temperature is alleviated in a synergistic fashion (Braun \& Khan, 1976; Rao et al., 1975).

It has also been reported that ethylene stimulates the synthesis of some enzymes (Cervantes et al., 1994; Hasegawa et al., 1995). Separation of cells because activation of cell wall degrading enzymes, such as endo- $\beta$ 1,4-glucanases, has been studied in other process, such as fruit softening (Casadoro et al., 1999). Other cell walldegrading enzymes, such as endopolygalacturonase, some isoforms of $\alpha$-galactosidase, $\beta$-arabinosidase, and galactanase, appear to have ethylene-dependency (Pech et al., 1999). In some fruits, the climacteric rise in ethylene is accompanied by an increase in $\alpha$-galactosidase and $\beta$-mannosidase activities (Moya et al., 1999). Possibly, ethylene might overcome the inhibitory effect of high temperature on lettuce seed germination by activating cell wall enzymes responsible for endosperm digestion.

Lettuce endosperm acts as a physical barrier to radicle protrusion at high temperatures (Sung, 1996). At high temperature, thresholds for enzymatic weakening of the endosperm may not be attained because of sub-optimal enzyme activity. Since the lettuce endosperm cell walls are composed largely of mannans, endo- $\beta$ mannanase might be a enzyme likely involved in cell wall degradation, leading to weakening of the endosperm and subsequent radicle protrusion. Recently, Nascimento et al. (1999a, 1999b, 2000a, 2000b) reported a relationship between ethylene evolution and endo- $\beta$-mannanase activ- ity before radicle protrusion. These authors suggested that the activity of endo- $\beta$-mannanase may be regulated by ethylene.

\section{Ethylene production}

The timing of ethylene synthesis during seed germination may be essential to clarify the role of ethylene in lettuce germination. Ethylene production by seeds begins immediately after the onset of imbibition and increases with time. However, the pattern of ethylene production by seeds during germination differs among species. For example, Takayanagi \& Harrington (1971) found a peak of ethylene evolution during germination of rapeseed coinciding with the emergence and elongation of the radicle, cotyledon expansion, and splitting of the seed coat. In oat seeds, ethylene production initiated prior to radicle protrusion and gradually increased (Meheriuk \& Spencer, 1964). In lettuce, a major surge in ethylene evolution was observed at the time of visible radicle protrusion (Fu \& Yang, 1983; Saini et al., 1986). However, Small et al. (1993) reported major increases in ethylene evolution after lettuce radicle protrusion. Nascimento et al. (2000a) observed that ethylene production in some lettuce genotypes was first detectable between 6 and 9 hours after imbibition at $20^{\circ} \mathrm{C}$, and between 9 and 12 hours after imbibition at $35^{\circ} \mathrm{C}$, before radicle protrusion. Perhaps, ethylene produced prior to radicle protrusion may be trapped beneath the integuments of the seed, reducing its detectability during radicle protrusion; subsequent rupture of the endosperm allows ethylene to be released.

The embryo is the major site of ethylene production (Ketring \& Morgan, 1969; Esashi \& Katoh, 1975). Ethylene concentrations which effectively stimulate seed germination of dormant seeds range on $0.1-200 \mu \mathrm{L} \mathrm{L}^{-1}$ depending on the species (Corbineau \& Côme, 1995). As for lettuce, $10 \mu \mathrm{L} \mathrm{L}^{-1}$ of ethylene has been reported to be optimal for promoting seed germination (Burdett \& Vidaver, 1971). The differential capacity of different cultivars to produce ethylene during stress generally corresponds to their ability to germinate at high temperature (Prusinski \& Khan, 1990). Genotypic variability in seed coat characteristics might influence ethylene production and performance of seeds under stressful conditions, either by reducing the performance of the growing embryo; by serving as a mechanical barrier; or by creating a hypoxic environment that impaired the conversion of ACC to ethylene (Prusinski \& Khan, 1990). In another study, Nascimento et al. (2000a) verified that thermotolerant lettuce genotypes produced more ethylene during seed germination at high temperatures than thermosensitive genotypes.

\section{Ethylene and seed vigor}

Improved performance of preconditioned lettuce seeds at high temperature is related to high vigor and 
greater capacity to produce ethylene (Huang \& Khan, 1992). Early studies suggested that ethylene may enhance vigor of some seeds and stimulate metabolism of seeds. In peanut and cotton seeds, decrease in vigor parallels the maximum amount of ethylene produced during germination (Ketring et al., 1974). Takayanagi \& Harrington (1971) observed that aged rapeseed produced less ethylene than did young seeds. As rapeseed vigor declined, a delay to reach maximum ethylene production occurred, and the germination rate of aged rapeseed was enhanced by exogenous ethylene. These authors suggested that aging affects ethylene-producing capability of the seeds and, apparently, also attenuate ethylene action since exogenous ethylene would no longer stimulate growth.

In lettuce, seed germination rate was accelerated by ethephon treatment, and practically all of germination increasing occurred during the first 24 hours after imbibition (Sharples, 1973). Nascimento et al. (1999c) observed lower ethylene levels at $35^{\circ} \mathrm{C}$ in aged seeds compared to non-aged lettuce seeds. These observations allow to infer that aging can lead to reduced ethylene and, consequently, lead to thermoinhibition.

\section{Ethylene inhibitors}

Involvement of ethylene in lettuce seed germination, particularly at high temperature, needs elucidative studies. A critical factor is the response of seed germination to various ethylene inhibitors. Aminoethoxyvinylglycine (AVG), an inhibitor of ethylene synthesis, has little influence on lettuce seed germination (Nascimento et al., 1999b). For example, germination of lettuce seeds at $35^{\circ} \mathrm{C}$ (Khan \& Prusinski, 1989) or at $25^{\circ} \mathrm{C}$ (Huang \& Khan, 1992) was not inhibited by AVG even though it inhibited ethylene production. These results suggest that, probably, seeds that germinated had a very low ethylene requirement, fulfilled by the residual ethylene synthesis occurring in the presence of AVG (Saini et al., 1986).

In addition, the threshold levels for ethylene action were not detectable possibly due to either restriction of ethylene from the seed coverings or production at lower levels than detectable or immediate utilization, or both. However, AVG and cobalt ions, reduce lettuce seed germination and the effect can be overcome by the addition of ethylene (Abeles, 1986).

Providing ACC either during priming or during lettuce seed germination increased endo- $\beta$-mannanase activity, whereas AVG and silver thiosulphate (STS) lead to a decrease or no activity (Nascimento et al., 1999b). Inhibitors of ethylene action, such as STS and 2,5norbornadiene, reduced lettuce seed germination and their effect can also be reversed by ethylene. For example, silver thiosulfate reduced lettuce seed germination of thermosensitive and thermotolerant genotypes at high temperature (Nascimento et al., 1999b). In recent study, STS-induced reduction in lettuce seed germination was found to be both temperature and concentration dependent (Kozareva et al., 2002). Increasing molarity of STS from 1 to 5,20 and $50 \mathrm{mmol} \mathrm{L}^{-1}$, reduced germination from $97 \%$ to $0 \%$ at $35^{\circ} \mathrm{C}$ and provided evidence for ethylene involvement in lettuce seed germination at supraoptimal temperature. Finally, these discrepancies have contributed to the consensus that ethylene plays a vital but still inconclusive role in lettuce seed germination.

\section{CONCLUSIONS AND PROSPECTS}

Ethylene can stimulate seed germination and overcome dormancy in lettuce. The inhibitory effect of high temperature on lettuce seed germination can be overcome by exogenous ethylene. The exact role for ethylene in germination is not known but ethylene evolution, ethylene addition and/or addition of ACC are associated with increased endo- $\beta$-mannanase, a cell-wall degrading enzyme that weakens the endosperm and allows the lettuce seed to germinate at high temperature. To elucidate the exact role of ethylene in lettuce seed germination at high temperature, further studies are needed. The use of other specific inhibitors of ethylene action might be a good approach. For instance, 1-methylcyclopropane (1$\mathrm{MCP}$ ), a gas-releasing compound, is a competitive inhibitor of ethylene action which binds to the ethylene receptor and suppress tissue responses to ethylene (Tian, 1998). In addition, the use of transgenic plants and/or mutants could facilitate the elucidation of the mechanisms of ethylene biosynthesis as well as the role of ethylene in seed germination.

\section{REFERENCES}

ABELES, F.B. Role of ethylene in Lactuca sativa cv. 'Grand Rapids' seed germination. Plant Physiology, v.81, p.780-787, 1986.

ABELES, F.B.; LONSKI, J. Stimulation of lettuce seed germination by ethylene. Plant Physiology, v.44, p.277-280, 1969.

ABELES, F.B.; MORGAN, P.W.; SALTVEIT JR, M.E. Ethylene and plant biology. 2. ed. San Diego: Academic Press, 1992.

BEAUDOIN, N.; SERIZET, C.; GOSTI, F.; GIRAUDAT, J. Interactions between abscisic acid and ethylene signaling cascades. The Plant Cell, v.12, p.1003-1115, 2002.

BRAUN, J.W.; KHAN, A.A. Alleviation of salinity and high temperature stress by plant regulators permeated into lettuce seeds via acetone. Journal of the American Society for Horticultural Science, v.10, p.716-721, 1976.

BURDETT, A.N. Antagonistic effects of high and low temperature pretreatments on the germination and pregermination ethylene synthesis of lettuce seeds. Plant Physiology, v.50, p.201-204, 1972a.

BURDETT, A.N. Ethylene synthesis in lettuce seeds: its physiological significance. Plant Physiology, v.50, p.719-722, 1972 b.

BURDETT, A.N.; VIDAVER, W.E. Synergistic action of ethylene with gibberellin or red light in germinating lettuce seeds. Plant Physiology, v.48, p.656-657, 1971.

CANTLIFFE, D.J.; SUNG, Y.; NASCIMENTO, W.M. Lettuce seed germination. Horticultural Reviews, v.24, p.229-275, 2000. 
CANTLIFFE, D.J.; NASCIMENTO, W.M.; SUNG, Y.; HUBER, D.J. Lettuce endosperm weakening: a role for endo-beta-mannanase in seed germination at high temperature. In: INTERNATIONAL WORKSHOP ON SEEDS, 6., Merida, México, 1999. Seed Biology: advances and applications; proceedings. Wallingford; CABI International, 2000, p. 277-285.

CASADORO, G.; TRAINOTTI, L.; TOMASIN, C.A. Expression of abcission-related endo- $\beta$-1,4-glucanases. In: EU-TMREUROCONFERENCE SYMPOSIUM ON BIOLOGY AND BIOTECHNOLOGY OF THE PLANT HORMONE Ethylene II, Biology and biotechnology of the plant hormone ethylene II; proceedings. Thira (Santorini); Kluwer Academic Publishers, 1999, p.243-247.

CERVANTES, E.; RODRIGUES, A.; NICOLAS, A. Ethylene regulates the expression of a cysteine proteinase gene during germination of chickpea Cicer arietinum L. Plant Molecular Biology, v.25, p.207-215, 1994.

CORBINEAU, F.; CÔME, D. Control of seed germination and dormancy by the gaseous environment. In: KIEGEL, J.; GALILI, G. (Ed.) Seed development and germination. New York: Marcel Dekker, 1995. p.397424.

DUNLAP, J.R.; MORGAN, P.W. Reversal of induced dormancy in lettuce by ethylene, kinetin, and gibberellic acid. Plant Physiology, v.60, p.222224, 1977

DUTTA, S.; BRADFORD, K.J. Water relations of lettuce seed thermoinhibition: II. Ethylene and endosperm effects on base water potential. Seed Science Research, v.4, p.11-18, 1994.

ESASHI, Y. Ethylene and seed germination, In: MATTOO, A.K.; SUTTLE, J.C. (Ed.) The plant hormone ethylene. Boca Raton : CRC Press, 1991. p.133-157.

ESASHI, Y.; KATOH, H. Dormancy and impotency of cocklebur seeds: III. $\mathrm{CO}_{2}$ - and $\mathrm{C}_{2} \mathrm{H}_{4}$-dependent growth of the embryonic axis and cotyledon segments. Plant Cell Physiology, v.16, p.707-718, 1975.

FU, J.R.; YANG, S.F. Release of heat pretreatmnet-induced dormancy in lettuce seeds by ethylene or cytokinin in relation to the production of ethylene and the synthesis of 1-aminocyclopropane-1-carboxylic acid during germination. Plant Growth Regulator, v.2, p.185-192, 1983.

GALLARDO, M.; DELGADO, M. DEL M.; SANCHEZ-CALLE, I.M.; MATILLA, A.J. Ethylene production and 1-aminocyclopropane-1carboxilic acid conjugation in thermoinhibited Cicer arietinum L. seeds. Plant Physiology, v.97, p.122-127, 1991.

GHASSEMIAN, M.; NAMBARA, E.; CUTLER, S.; KAWAIDE, H.; KAMIYA, Y.; McCOURT, P. Regulation of abscisic acid signaling by the ethylene response pathway in arabidopsis. The Plant Cell, v.12, p.11117-1126, 2002.

HASEGAWA, R.; MARUYAMA, A.; NAKAYA, M.; TSUDA, S.; ESASHI, Y. The presence of two types of $\beta$-cyanoalanine synthase in germinating seeds and their responses to ethylene. Physiologia Plantarum, v.93, p.713-718, 1995.

HUANG, X.-L.; KHAN, A.A. Alleviation of thermoinhibition in preconditioned lettuce seeds involves ethylene, not polyamine biosynthesis. Journal of the American Society for Horticultural Science, v.117, p.841-845, 1992.

KETRING, D.L. Ethylene and seed germination. In: KHAN, A.A. (Ed.) The physiology and biochemistry of seed dormancy and germination. Amsterdam: North Holland Publishing, 1977. p.157-178.

KETRING, D.L.; MORGAN, P.W. Ethylene as a component of the emanations from germinating peanut seeds and its effect on dormant Virginia-type peanut seeds. Plant Physiology, v.44, p.326-330, 1969.

KETRING, D.L.; MORGAN, P.W. Physiology of oil seeds: I. Regulation of dormancy in Virginia-type peanut seeds. Plant Physiology, v.45, p.268-273, 1970.

KETRING, D.L.; MORGAN, P.W.; POWELL, R.D. Relations of ethylene production to germinability and growth of two oil seeds, cotton and peanuts. In: SUMIKI, Y. (Ed.) Plant growth substances. Hirokawa, Tokyo: 1974. p.891-899.

KEYS, R.D.; SMITH, O.E.; KUMAMOTO, J.; LYON, J.L. Effect of gibberellic acid, kinetin, and ethylene plus carbon dioxide on the thermodormancy of lettuce seed (Lactuca sativa L. cv. Mesa 659). Plant Physiology, v.56, p.826-829, 1975.

KHAN, A.A.; HUANG, K.-L. Synergistic enhancement of ethylene production and germination with kinetin and 1-aminocyclopropane-1carboxylic acid in lettuce seeds exposed to salinity stress. Plant Physiology, v.87, p.847-852, 1988.
KHAN, A.A.; PRUSINSKI, J. Kinetin enhanced 1-aminocyclopropane-1carboxylic acid utilization during alleviation of high temperature stress in lettuce seeds. Plant Physiology, v.91, p.733-737, 1989.

KOZAREVA, I.; CANTLIFFE, D.J.; NAGATA, R.T.; KLEE, H.J. New support for the involvement of ethylene in lettuce germination at supraoptimal temperature. In: INTERNATIONAL HORTICULTURAL CONGRESS, 25.; Proceedings. Toronto, 2002. p.549.

MEHERIUK, M.; SPENSER, M. Ethylene production during germination of oat seeds and Penicillium digitatum spores. Canadian Journal of Botany, v.42, p.337-340, 1964.

MORGAN, P.W. ; DREW, M.C. 1997. Ethylene and plant responses to stress. Physiologia Plantarum, v.100, p. 620-630.

MOYA, M.A.; MOGGIA, C.; EYZAGUIRRE, J.; JOHN, P. Softening in apples and pears. The role of ethylene and several cell wall degrading enzymes. In: EU-TMR-EUROCONFERENCE SYMPOSIUM ON BIOLOGY AND BIOTECHNOLOGY OF THE PLANT HORMONE Ethylene II, Biology and biotechnology of the plant hormone ethylene II; proceedings. Thira (Santorini); Kluwer Academic Publishers, 1999, p.431-432.

NASCIMENTO, W.M. Involvement of ethylene and endo- $\beta$-mannanase in lettuce seed germination at high temperature. Gainesville: University of Florida, 1998. (Thesis - Doctor)

NASCIMENTO,W.M.; CANTLIFFE, D.J. Circumventing thermodormancy in lettuce. Acta Horticulturae, n.504, p.147-152, 1999.

NASCIMENTO, W.M.; CANTLIFFE, D.J. Produção de etileno, atividade de endo- $\beta$-mananase e germinação de sementes de alface em resposta a luz e temperatura. Revista Brasileira de Sementes, v.22, p.1-5, 2000.

NASCIMENTO, W.M.; CANTLIFFE, D.J.; HUBER, D.J. Lettuce seed germination and endo- $\beta$-mannanase activity at high temperature is stimulated by ethylene. HortScience, v.34, p.513, 1999a.

NASCIMENTO, W.M.; CANTLIFFE, D.J.; HUBER, D.J. Endo- $\beta$ mannanase activity during lettuce seed germination at high temperature in response to ethylene. In: EU-TMR-EUROCONFERENCE SYMPOSIUM ON BIOLOGY AND BIOTECHNOLOGY OF THE PLANT HORMONE Ethylene II, Biology and biotechnology of the plant hormone ethylene II; proceedings. Thira (Santorini); Kluwer Academic Publishers, 1999b. p.191-192.

NASCIMENTO, W.M.; CANTLIFFE, D.J.; HUBER, D.J. Lettuce seed germination at high temperature: endo-beta-mannanase activity and ethylene production in response to seed vigor. In: INTERNATIONAL WORKSHOP ON SEED BIOLOGY, 6., Merida Yucatan, 1999. Program and abstracts presentations. Merida Yucatan, 1999c. p.103.

NASCIMENTO, W.M.; CANTLIFFE, D.J.; HUBER, D.J. Thermotolerance in lettuce seeds: association with ethylene and endo- $\beta$-mannanase. Journal of the American Society for Horticultural Science, v.125, p.518-524, 2000a.

NASCIMENTO, W.M.; CANTLIFFE, D.J.; HUBER, D.J. Endo- $\beta$ mannanase activity during lettuce seed germination at high temperature conditions. Acta Horticulturae, n.517, p.107-111, 2000b.

NEGM, F.B.; O.E. SMITH. Effects of ethylene and carbon dioxide on the germination of osmotically inhibited lettuce seed. Plant Physiology, v.62, p.473-476, 1978.

NEGM, F.B.; SMITH, O.E.; KUMAMOTO, J. Interaction of carbon dioxide and ethylene in overcoming thermodormancy of lettuce seeds. Plant Physiology, v.49, p.869-872, 1972.

OLATOYE, S.T.; HALL, M.A. Interaction of ethylene and light on dormant weed seeds. In: HEYDECKER, W. (Ed.) Seed ecology. London: Butterworths, 1972, p.233-249.

PECH, J.C.; AYUB,V.; LATCHE, A. Ethylene-dependent and ethylene independent pathways in the melon. In: EU-TMR-EUROCONFERENCE SYMPOSIUM ON BIOLOGY AND BIOTECHNOLOGY OF THE PLANT HORMONE Ethylene II. Biology and biotechnology of the plant hormone ethylene II; proceedings. Thira (Santorini); Kluwer Academic Publishers, 1999. p.105-110.

PRUSINSKI, J.; KHAN, A.A. Relationship of ethylene production to stress alleviation in seeds of lettuce cultivars. Journal of the American Society for Horticultural Science, v.115, p.294-298, 1990.

RAO, V.S.; SANKHLA, N.; KHAN, A.A. Additive and synergistic effect of kinetin and ethrel on germination, thermodormancy, and polyribosome formation in lettuce seeds. Plant Physiology, v.56, p.263-266, 1975. 
SAINI, H.S.; CONSOLACION, E.D.; BASSI, P.K.; SPENCER, M.S. Requirement for ethylene synthesis and action during relief of thermoinhibition of lettuce seed germination by combinations of gibberellic acid, kinetin, and carbon dioxide. Plant Physiology, v.81, p.950-953, 1986.

SAINI, H.S.; CONSOLACION, E.D.; BASSI, P.K.; SPENCER, M.S. Control processes in the induction and relief of thermoinhibition of lettuce seed germination. Actions of phytochrome and endogenous ethylene. Plant Physiology, v.90, p.311-315, 1989.

SHARPLES, G.C. Stimulation of lettuce seed germination at high temperatures by ethephon and kinetin. Journal of the American Society for Horticultural Science, v.98, p.209-212, 1973.

SMALL, J.G.C.; SCHULTZ, C.; CRONJE, E. Relief of thermoinhibition in 'Grand Rapids' lettuce seeds by oxygen plus kinetin and their effects on respiration content of ethanol and ATP and synthesis of ethylene. Seed Science Research, v.3, p.129-135, 1993.

STEWART, E.R.; FREEBAIRN, H.T. Ethylene, seed germination, and epinasty. Plant Physiology, v.44, p.955-958, 1969.
SUNG, Y. Identification and characterization of thermotolerance in lettuce seed germination. Gainesville: University of Florida, 1996. (Thesis Doctor)

TAKAYANAGI, K.; HARRINGTON, J.F. Enhancement of germination rate of aged seeds by ethylene. Plant Physiology, v.47, p.521-524, 1971.

TIAN, M.S. Responses of strawberry fruit to 1-MCP and ethylene. Biology and biothecnology of the plant hormone ethylene II. (Island of Santorini, Cyclades, Greece). Abstract \# 48, pg. 89. Sept. 5-8, 1998.

YOSHIYAMA, M.; YAJIMA, H.; TADAHIRO, A.; ESASHI,Y. Mechanism of action of $\mathrm{C}_{2} \mathrm{H}_{4}$ in promoting the germination of cocklebur seeds: II The role of $\mathrm{C}_{2} \mathrm{H}_{4}$ in the enhancement of priming effects. Australian Journal of Plant Physiology, v.23, p.133-139, 1996.

YU, Y.-B.; ADAMS, D.O.; YANG, S.F. Inhibition of ethylene production by 2,4 dinitrophenol and high temperature. Plant Physiology, v.66, p.286-290, 1980.

Received March 20, 2002

Accepted April 16, 2003 